\title{
Teacher Professional Development
}

\author{
Zakiyuddin \\ Camp team of language Center Kampung Inggris Pare \\ Vegeancezacky89@gmail.com
}

\begin{abstract}
The information has a paradoxical impact to our life of the nation and state, one way to reduce it is through education. The aim of education is to develop self - potential in order to have spiritual power, Personality, intelligence, morals. Education to address the challenge above, needed education which oriented to relevant need globally (Global relevant need). Therefore, education needs reliable sources, both human resources and infrastructure for education efficiency. Education efficiency will be achieved when it is available resource which has ability in managing education and managing calculation. Currently In our education world emblazoned two concepts which have big influence to wisdom are professional and teacher certification. Both of them have psychology impact to the implementation of learning activity. There are two important basic systems are teacher and curriculum. We know that our curriculum always changes and the teacher still occupies in dominant position.
\end{abstract}

Keyword: professional development

\section{INTRODUCTION}

Education sector has very strategic role in enhancement of human resources. Indonesian which has ability to face competitive challenges in future. At the present level, the enhancement of human resources becomes priority in developing a country. There is no other way to develope it except by improving the quality of education.

The education quality is determined by many factors, such as including input, process, environmental support and infrastructure. Input related to conditions of students (interest, ability, potential, motivation and attitude ), process related to creation of learning atmosphere, which in this case emphasizes more on teacher creativity, environmental support which is related to atmosphere or condition which supports to all of learning process is like family environment, society, natural surroundings, while the infrastructure is the tool to facilitate the learning activities, such as shed, laboratorium tools and others.

Related to process, teacher is one of the basic to create a learning atmosphere. teacher is the key to improve the education quality, so the teacher is needed requirements to be called as the professional teacher. According to Ace Suryadi ( 2004 ) the quality teacher must have four requirements are : 1) professional ability ( professional capasity ), 2) professional effort ( professional effort), 3) the time for doing the professional activities ( time devotion ), and 4) the return of his job ( professional rent )

Teacher professional development is presented in different ways, But at the core is the understanding that teacher professional teacher is about teacher learning, learning how to learn, and transforming the knowledge for behalf of student knowledge .
There are many ways to improve the teacher professional that has been provided by the government through are the education qualification development, training, workshop, the teacher certification program and teacher welfare development.

\section{THE DEFINITION OF PROFESSIONALISM}

Professionalism Comes from english language which means the nature of professional. According to Jasin and anwar, professionalism is the commitment of the members in a profession to improve the ability of their professionalism. According to indonesia dictionary, profession is the field of the work wich is based on education. Proefessionalism is related to the profession, it is needed a special intelligence to run it.

According to rice and bishoprick in ibrahim bafadal that the professional teacher is the teacher who is able to manage himself in doing his activities. According to surya, professionalism is various abilities which are needed to realize himself as the professional

We can conclude that professionalism is the ability which is owned by the teacher to run his duties and his obligation

The characteristic of professional teacher According to suprihatiningrum cited from Houle are :

1. must have the strong knowledge base

2. Must be based on individual competence

3. Having selection system and certification

4. Healthy Teamwork and competition

5. The high Professional realization

6. Having principles and ethics code

7. Having system of profession sanction

8. Having profession organization

Based on law, number, 2005/14 that a teacher must have education backround at least undergraduate. Professional teacher must have clear aim in learning process, having a good skill class management.

Meanwhile according to Suyanto and Asep Jihad the characteristics of professional teachers are:

1. Teacher theory and practice

2. Nice to invite teacher professional organizations

3. Having an adequate teacher education background

4. Implementing the teacher's code of ethics

5. Having autonomy and a sense of responsibility

6. Having a sense of community service.

Professional Teacher Terms The professional teacher requirements according to Islamic education, namely: 
1. Fear

2. Extensive Knowledge

3. Fair applies

4. Authority

5. Sincerity

6. Having Rabbani's Purpose; Where everything rests on God and always obeys it, serving is invited to follow the Shari'a, and recognize its characteristics.

7. Able to Plan and Implement Evaluations.

8. Mastering the Specified Field.

\section{EDUCATOR AS THE POWER OF PROFESSIONALISM}

Teacher decides the future of our nation. in teacher's hand, our nation future will be decided. While the improving of the quality of the adult education will get the obstacle which is difficult to solve it. There are many students who stop studying, there are many candidates of teacher, but they are not excellent. Actually the effort of improving the quality of students from a year to a year always becomes the government's program. The education quality is effected by the improvement of integral from all of education components like the teacher quality, spreading equal teacher, the curriculum which is always improved any time, the perfect infrastructure, the conducive learning atmophere, and the quality of teacher who always develops and supported by the goverment wisdom.

The professional teacher not only masters one sector of science but also the learning material, mastering the methode and also able to motivate the students.

The professional indonesian teacher must have; (1) the strong basic science as the tool to face technology society and the knowledge society in this century; (2) the mastery of profession based on the research and education practice that is education science as the science of practice not only concept, (3) developing the ability of professionalism, the profession of teacher is the profession which must develop continuously

UUD. Number 14 year 2005 about the teacher and lecturer pasal 8 stated that teacher must have the qualification of academic, competence, certificate of educator, healthy of physical and spiritual, and also must have the ability to realize the aim of national education.

\section{Teacher Competence}

professional teacher can be realized through potential empowement and teacher achievement. A teacher is called as professional teacher because of his ability in realizing teacher profession performance. In other word, the teacher must have a good competence. Competence is a set of ability mastery which must exist in every teacher to realize our professional performance.

Based on law, number 14, year 2005 about the teacher and lecturer pasal 10 verse (1) states that a teacher must have 4 competences, including ; pedagogic competence, personality competence, social competence and professional competence

1. Pedagogic Competence

Pedagogic competence is the ability of teacher in managing of learning and understanding the students which cover the comprehension to the students. Plannig and implementation the learning, evaluating the result of learning, and developing the students to act many potentials.

Pedagogic competence in PP. RI about teacher Number. 74 year 2008 pasal 3, verse 4 must be acted by teacher to the students at least

a. Understanding the concept or the educational base

b. Uderstanding to the students

c. Developing the curriculum or syllabus

d. Planning the learning

e. The implementation of dialogic educational learning

f. Utilization the learning technology

g. Evaluate the result of learning

h. Developing the students to act many potentials

2. Professional competence

Professional competence is the ability to master the lesson widely and deeply enable to guide the students to fill the standard of competence which is determined in standard of education national education

In education, the profession of teacher there are many competences which must be realized by professional teacher, according to TIM PPG ( 2008 ) are :

a. Curriculum structure of education which is same direction with specificity of study program / lesson

b. Substansial with IPTEKSA that will be learned

c. Strategy application, methode, and learning technique.

d. Source and learning media

e. Assesment and learning evaluation

f. Improvement teaching and enrichment

g. Learning practice (internship)

h. Education research and learning

i. The role of profession organization and ethic code of teacher profession

3. Personality competence

Personality competence is the steady ability, stable, adult, wise authority, and be the example 
for the students, and good moral. Personality competence is the picture of perfect teacher as the model, sample.according to TIM PPG ( 2008 ) the ability of personality including

a. Religious personality and godly, morals, independent, and sample.

b. High appreciation to dignity and human life which envolve and beatify

4. Social competence

Social competence is the ability of educators as part of community to communicate and get along effectively with participants students, fellow educators, education staff, parents/ guardians of students, and the surrounding community. According to PPG TEAM (2008) it is abilities related to

a. Relationship between individuals, colleagues profession, and relationship with parents, environment/ community, interorganization and between organizations profession

b. Collaborative relationshipwith other professional skills, team building cooperation ( team building), cooperation (team collaboration), and responsibility ( team responsibility )

To be professional at in addition to the competencies above a teacher also demanded several things, namely :

1. The teacher is committed to students and their learning process. This commitment is proven by giving full time for education. Fill in the day with the desire to educate the nation, read, write, become a speaker, research. This matter also proven by discipline the teacher in teaching, provides time for deep learners provide guidance and training,and continue to improve quality learning

2. The teacher masters deeply material / subjects taught and how to teach them. Extensive scientific mastery and deep and able to connect material with the lives of participants students and links with eyes other lesson must continue to be developed. Means of development can be in the KKG or MGMP or teacher seminar forums others. Besides mastery matery, a teacher is required to be able to teach it according to the characterisric of students

3. Teacher are responsible for monitoring student learning outcomes through various evaluation method. The teacher must be able to assess the process and learning outcomes of students, as well as master the way, evaluate the process and learning outcomes well. Assessment is done not only cognitive assessment but also by assessing affective and aspects psychomotor learners. One of success factors of students is the accuracy of the teacher in carrying out an assessment of the process and results learning of students

4. The teacher is able to think systematically what he did and what learn from his expriences. Besides that, the teacher must also be able to think systematically towards the work, so that the teacher is able to carry out it effective teaching assignments and efficient

S

5. The teacher should be part from the learning community in their professional environment. Teachers also must always learn because the teacher is part of community. The definition of studying forever always becomes teacher's motto until becoming professional teacher.

\section{THETEACHER'S PROFESSIONALISM IMPROVEMENTPATH}

This implies that the LPTK as the printer of the prospective teacher needs to equip its graduates with development latest knowledge and skills in accordance with the times and developments according to the needs of the field. While this still impressed the LPTK late in anticipating this. An example is the development of learning innovations such as Quantum Learning model, Quantum Teaching and other models, some LPTKs have not included models into the curriculum.

The source of science is not again centered on educational institutions formal (elementary, middle, high school, college) high) conventional. Source of knowledge knowledge will spread everywhere and everyone will easily acquire knowledge without difficulty. This paradigm is known as distributed intelligence (distributed knowledge). The function of the teacher / lecturer / educational institution has finally shifted from a source of knowledge to a mediator from science Are LPTKs also ready with this condition and equip graduates with field conditions?

1. Enhancing Teacher Professionalism Through the Learning / Equalization Task Program

One way to improve teacher professionalism is through a minimum diploma standard must be owned by the teacher. In accordance with the demands of the Teacher and Lecturer Law that the minimum of teacher education is SI (DIV)

There are at least three things that can achieved by giving assignments to the teacher is both a 
Following the actual news, 12) Participating and being active in the organization profession and 13) Raising cooperation with your friends

\section{CONCLUSION}

Teacher professionalism can be seen from the level of education, mastery of competencies become responsive to the teaching profession, namely: pedagogic competence, personality competence, social competence, and professional competence. Besides that there is also several other dimensions as benchmarks teacher of professionalism.

Much can be done to improve professionalism teachers appreciate are: 1 program Improvement of teacher qualifications, 2 Program equalization and certification, 3 Program competency-based integrated training, 4) education supervision program,5 MGMP empowerment program, 6 Teacher symposium, 7 Traditional programsothers, 8 Read and write a journal or scientific work, 9 Participatein scientific meetings, 10 do Research, 11 Internships, 12 Following

actual news, 13 Participate and be active in professional organizations and 13 Collaborate with friends colleague

\section{REFERENCES} the area so that it does not seem centralized, so that monitoring and evaluation is difficult to do. With this method also began to empower the area to be responsible for development of teacher professionalism

3. Enhancing Teacher Professionalism Through Educational Supervision / Supervision

Supervision and supervision in schools can function for development, motivation and control if implemented by holding the principles of education supervision and supervision. Through supervision, a harmonious and open humanitarian relationship can be created between teachers and supervisor In this way the teacher can motivated to always improve performance in the learning process.

Director General of Ministry of Education and Culture National Education mentions several alternative development programs teacher professionals as follows: 1) Teacher qualification improvement program, 2) Equalization and certification program, 3) Integrated training program based competence, 4) education supervision program, 5) empowerment program MGMP, 6) Teacher Symposium, 7) Program other traditional, 8) Reading and write a journal or scientific work, 9) Participate in scientific meetings, 10) Conducting Research, 11) Internships, 12)
Arifin, I. 2000. Profesionalisme Guru: Analisis Wacana Reformasi Pendidikan dalam Era Globalisasi. Simposium Nasional Pendidikan di Universitas Muhammadiyah

Malang, 25-26 Juli 2001.

Ace Suryadi dan Wiana Mulyana, 1992. Kerangka Konseptual Mutu Pendidikan dan Pembinaan Kemampuan Profesional Guru, Jakarta: PT.Candimas Metropole Jakarta: Adicita Karya Nusa.

Hamijoyo, Santoso S. 2002. "Status dan Peran Guru, Akibatnya Pada Mutu Pendidikan". dalam Pendidikan untuk Masyarakat Indonesia Baru. Jakarta: Grasindo.

Kompas. 2010. "Tantangan Ilmua Pendidikan". (30 Desember 2010) Syaiful Sagala, 2009. Kemampuan Profesional Guru dan Tenaga Kependidikan, Bandung: Alfabeta. Supriadi, D. 1998. Mengangkat Citra dan Martabat Guru. Jakarta:

Depdikbud.

Tilaar, H.A.R. 1999. Beberapa Agenda Reformasi Pendidikan Nasional dalam Perspektif Abad 21. Magelang: Indonesia Tera. 
Undang-Undang Republik Indonesia No. 20 tahun 2003 tentang

Pendidikan Nasional (Sisdiknas).

Saudagar dan Idrus,Pengembangan Profesionalitas Guru

(Jakarta: Gaung Persada, 2009),

h. $\quad$ 96-97.

Kemendikbud RI,Kamus Besar Bahasa Indonesia, Ed. 3

(Jakarta: Balai Pustaka, 2007),

h. $\quad 584$.

Undang-undang RI No. 14 Tahun 2005 bab 1 Pasal 1 ayat 4,Tentang Guru dan Dosen.

Trianto,Pengantar Penelitian Pendidikan Bagi Pengembangan Profesi Pendidikan dan Tenaga Kependidikan (Jakarta: Kencana Prenada Media Group, 2010), h. 18-19. .Hamzah B. Uno,Profesi Kependidikan (Jakarta: Bumi Aksara, 2009), h. 15.

Ibrahim Bafadal,Peningkatan Profesionalisme Guru Madrasah Dasar (Jakarta: Bumi
Aksara,
2006),
h.
5.

Kemendikbud RI,Kamus Besar Bahasa Indonesia (Jakarta:
Balai
Pustaka,
1993),
$\mathrm{h}$.
288.3

Ngalim Purwanto,Ilmu Pendidikan Teoritis dan Praktis (Bandung: Remaja Rosdakarya, 1994), h. 126.

Iskandar Agung,Mengembangkan Profesionalitas Guru: Upaya Meningkatkan Kompetensi dan Profesionalisme Kinerja Guru (Jakarta: Bee

Media Pustaka, 2014), h.. 75.

Sri Banun Muslim,Supervisi Pendidikan Meningkatkan

Kualitas Profesionalisme Guru

(Bandung: Alfabeta, 2010), h. 114. 